\title{
Biodegradation of Drilling Fluid used in Upstream Sector of the Nigeria Petroleum Industry in Marine Water Environment
}

\author{
Renner Renner Nrior, David N Ogbonna* and Alaumogute Edward Alabo
}

Department of Microbiology, Rivers State University, Nkpolu-Oroworukwo, PMB 5080, Port Harcourt, Nigeria

\begin{abstract}
Biodegradation of drilling fluid (water based and oil based drilling fuild) used in the upstream sector of the Nigeria petroleum industry was investigated in marine water environment. Drilling fluid were obtainedfrom Izombe well drilling site Owerri and marine water sample from Bonny River, Nigeria. The methodology of ultimate biodegradability estimated from the ratio of Biochemical Oxygen Demand to Chemical Oxygen Demand was used to determine biodegradability. Evaluation of percentage (\%) ultimate biodegradation at day 20; showed that water based drilling fluid had $59.5 \%$ to be more biodegradable than Oil based drilling fluid with $54.2 \%$. Drilling fluid utilizing bacteria genera isolated were: Pseudomonas, Bacillus, Micrococcus and Enterobacter, with Pseudomonas having the highest frequency of $35.7 \%$, followed by Bacillus with the frequency of $30.7 \%$, Micrococcus had $15.4 \%$ and Enterobacter $15.4 \%$.Fungi genera isolated include Aspergillus, Penicillium, Rhizopus Mucor. Conclusively, the study showed that water based drilling fluid is more biodegradable in marine water environment than oil based drilling fluid. Therefore it is recommended that since most oil well drilling activities in Nigeria are carried out in marine environments, water based drilling fluid should be the best option due to its high degradability rate.
\end{abstract}

Keywords: Biodegradation; Water based drilling fluid; Oil based drilling fluid; Marine water environment; Petroleum industry; Microorganisms

\section{Introduction}

Biodegradation is the breakdown of an organic substance, such as oil by the action of microorganisms, especially bacteria [1]. Some substances biodegrade more rapidly and more completely than others. Biodegradation may occur under both aerobic (with oxygen) and anaerobic (without oxygen) conditions, if the contamination is well dispersed in water there is usually more oxygen available for aerobic biodegradation. Water based muds is more readily dispersed than oilbased muds because it is water soluble. Drilling fluids are mixture of natural and synthetic chemical compounds used to cool and lubricate the drill bit; clean the hole bottom; carry cuttings to the surface, control formation pressure and improve the function of the drill string and tools in the hole [2]. Microorganisms are known to be ubiquitous and also adapt to the environment for effective competition for available nutrient. However the introduction of drilling fluid alters the environment causing a selection of those microorganisms capable of degrading petroleum [3]. Water Base Fluid (WBF) is the drilling fluid, in which fresh salt, or sea water is the continuous phase and it is the most used fluid (90-95\%). The WBM are mainly composed of aqueous solutions of polymers and clays in water or brines, with different types of additives incorporated to the aqueous solution. Oil Base Fluid (OBF); Oil base fluid is less used (5-10\%). These drilling fluids have been developed for situations where WBF were found inadequate. The $\mathrm{OBM}$ are oil (usually gas oil) based muds. Generally, they are invert emulsions of brine into an oil major, continuous phase stabilized by surfactants. Also other additives are often added to the organic phase such as organophilic modifiers of the clay surface. However OBM often give better performances, they have major drawbacks such as to be generally more expensive and less ecologically friendly than WBM. Consequently, although OBM give greater shale stability than WBM [4]. These later systems have also been developed by researchers in order to respond to environmental regulations $[5,6]$.

The biodegradability of petroleum products is dependent on the chemical structure of their various components. Compound resistance to biodegradation increases with increasing molecular weight. The oils used in OBM can be classified according to their aromatic hydrocarbon concentration, which contributed to fluid toxicity. However, the relations between hydrocarbon physio chemical properties and biodegradability have been little studied. Several works [7] dealing with laboratory techniques of biodegradability determination and the influence of experimental conditions, showed the variation of the results according to the used method and considered conditions. In general, the soluble, lighter petroleum hydrocarbons are more biodegradable than the less soluble, heavier members of the group. Viscosity is also known to have an important impact on biodegradability. Highly viscous hydrocarbons are less biodegraded because of the inherent physical difficulty in establishing contact among contamination and microorganisms, nutrients and electron acceptors components [8]. In the biodegradation process, it is pertinent that the only carbon source should be petroleum products. This otherwise would not slow down the biodegradation rates as the microorganism will turn to alternative carbon sources as a source of energy thus leaving behind the hydrocarbon. More so, hydrocarbon degrading microorganisms require nitrate and phosphate for growth, limitation of these substrates affects the rate and extent of degradation of petroleum in soil environment $[9,10]$. The aim of this research work was to evaluate the biodegradation rate of the two major types of drilling fluid (Water based drilling fluid and oil based drilling fluid) often employed in the upstream sector of the Nigeria Petroleum Industry in marine water environment.

${ }^{*}$ Corresponding author: Ogbonna DN, Department of Microbiology, Faculty of Science, Rivers State University, Nkpolu-Oroworukwo, PMB 5080, Port Harcourt, Nigeria, Tel: +234-7061103614; E-mail: ogbonna.david@ust.edu.ng

Received September 08, 2017; Accepted September 12, 2017; Published September 19, 2017

Citation: Nrior RR, Ogbonna DN, Alabo AE (2017) Biodegradation of Drilling Fluid used in Upstream Sector of the Nigeria Petroleum Industry in Marine Water Environment. Int J Waste Resour 7: 302. doi: 10.4172/2252-5211.1000302

Copyright: (C 2017 Nrior RR, et al. This is an open-access article distributed under the terms of the Creative Commons Attribution License, which permits unrestricted use, distribution, and reproduction in any medium, provided the original author and source are credited. 


\section{Materials and Methods}

\section{Sources of sample}

The marine water sample was collected with sterile plastic containers from Bonny River in Bonny Local Government Area of Rivers State. Each sample bottle was rinsed with the appropriate sample before the final collection according to the standard methods [11]. To collect the water sample, base of the sterilized sample bottle was held with one hand, plunged about $30 \mathrm{~cm}$ below the water surface with the mouth of the sample container positioned in an opposite direction to water flow [11]. The drilling fluid, water based and oil based drilling fluids were collected with sterile plastic containers from Adax petroleum company, Izombe well Owerri, Imo State Nigeria.

\section{Set up for drilling fluid contaminated marine water}

About $302 \mathrm{ml}$ of the marine water sample collected from Bonny River was dispensed into three different $500 \mathrm{ml}$ Erlenmeyer flask. After that, $1 \%(3 \mathrm{ml})$ of the oil base drilling fluid was dispensed into one of the Erlenmeyer flask containing $302 \mathrm{ml}$ of marine water, another $3 \mathrm{ml}$ of water base drilling fluid was dispensed into the second Erlenmeyer flask while the third Erlenmeyer flask was not contaminated with drilling fluid and was used as control.

\section{Media used}

The medium used for isolation in the study were:

(i) Nutrient Agar: Nutrient agar is a general purpose medium for the isolation of non- fastidious bacteria.

(ii) Water base agar: A medium used for the isolation of water base fluid utilizing bacteria.

(iii) Oil base agar: A medium used for the isolation of oil base fluid utilizing bacteria.

(iv) Sabouraud Dextrose Agar: used for fungi.

\section{Preparation of the media}

Nutrient agar: The nutrient agar was prepared according to manufacturer's specification. 28 grams of nutrient agar was dissolved in 1 litre of distilled water. All mixed in conical flask covered with cotton wool and aluminum foil to prevent moisture.

Water base agar: Water base agar was prepared by using agar-agar according to manufacturer's specification. The following ingredients were added $\mathrm{K}_{2} \mathrm{HPO}_{4} 0.5 \mathrm{~g}, \mathrm{MgSO}_{4} 7 \mathrm{H}_{2} \mathrm{O} 0.3 \mathrm{~g}$, Nacl $0.3 \mathrm{~g}, \mathrm{MnSO}_{4} \cdot \mathrm{H}_{2} \mathrm{O}$ $0.2 \mathrm{~g}, \mathrm{FeSO}_{4} \cdot 6 \mathrm{H}_{2} \mathrm{O} 0.02 \mathrm{~g}, \mathrm{NaNO}_{3} 0.03 \mathrm{~g}, \mathrm{ZnCl}_{2} 0.3 \mathrm{~g}$, water base fluid $1 \mathrm{ml}$, distilled water $200 \mathrm{ml}$

Oil base agar: Oil base agar was prepared by using agar-agar according to manufacturer's specification. The following ingredients were added $\mathrm{K}_{2} \mathrm{HPO}_{4} 0.5 \mathrm{~g}, \mathrm{MgSO}_{4} 7 \mathrm{H}_{2} \mathrm{O} 0.3 \mathrm{~g}, \mathrm{Nacl} 0.3 \mathrm{~g}, \mathrm{MnSO}_{4} \cdot \mathrm{H}_{2} \mathrm{O}$ $0.2 \mathrm{~g}, \mathrm{FeSO}_{4} \cdot 6 \mathrm{H}_{2} \mathrm{O} 0.02 \mathrm{~g}, \mathrm{NaNO}_{3} 0.03 \mathrm{~g}, \mathrm{ZnCl}_{2} 0.3 \mathrm{~g}$, oil base fluid $1 \mathrm{ml}$, distilled water $200 \mathrm{ml}$.

Sabouraud dextrose agar: Prepared according to the manufacturer's specification.

\section{Isolation of test organism}

An aliquot $(0.1 \mathrm{ml})$ of undiluted sample collected with a sterile pipette was inoculated in freshly prepared nutrient agar plate, oil base agar plate, water base agar plate and Sabouraud Dextrose agar plate. The inoculum was spread on the surface of the medium using sterile bent glass rod. The bent glass rod was sterilized by dipping it into a container containing alcohol and flaming a bit. The inoculated plates were inverted and incubated at $37^{\circ} \mathrm{C}$ for 24 hours for nutrient agar, 2-3 days for sabouraud dextrose agar, 5-7 days for both oil base and water base agar. After which colonies which developed were counted and recorded. Discrete colonies were randomly picked and sub-cultured on a freshly prepared nutrient agar and SDA plates respectively. To obtain pure cultures, the pure isolates were inoculated onto MaCartney bottle containing agar slant and incubated at $37^{\circ} \mathrm{C}$ for 24 hours, freshly prepared SDA plates were used for fungi pure isolates (each isolate per plate incubated at $37^{\circ} \mathrm{C}$ for $2-3$ days) after which they were removed and stored in the refrigerator for future use $[12,13]$.

\section{Identification of bacterial and fungal isolates}

The cultural, morphological and biochemical characteristics of the discrete bacterial isolates were compared with the recommendation in Bergey's Manual of Determinative Bacteriology (1984). The morphological and biochemical test include; gram staining, motility, catalase, oxidase, citrate utilization, hydrogen sulphide production, indole production, methyl red and Voges Proskauer tests. The presence or absence of septa in the mycelium, type of spore, presence of primary or secondary sterigmata, and other microscopic characteristics as well as cultural characteristics were used in the identification of the fungal isolates of the biodegradation flask set up [14].

\section{Percentage (\%) biodegradation evaluation}

The percentage (\%) biodegradation rate is calculated from the la used by [15] as follows:

Step 1: Amount of pollutant remediated equals to Initial concentration of pollutant (Day 0) minus final concentration of pollutant at end of experiment (last day).

Step2: Percentage (\%) bioremediation equals to amount of pollutant remediated divided by initial concentration of pollutant (Day 0 or 1 ) multiplied by 100 .

Thus;

$B_{C}=I_{C}-F_{C}$

$B x=I c-I_{0}$

Where,

$\mathrm{B}_{\mathrm{C}}=$ Amount of pollutant degraded

$\mathrm{I}_{\mathrm{C}}=$ Initial concentration of pollutant (Day 0)

$\mathrm{F}_{\mathrm{C}}=$ Final concentration of pollutant at end of experiment (Last day)

$\mathrm{I}_{0}=$ Initial concentration value of Control at day 0

$\mathrm{Bx}=$ Actual amount of pollutant in test medium

$\%$ Bioremediation $=\underline{B}_{\underline{C}} \underline{x 100}$

$B_{x}$

\section{Biodegradation of drilling fluid monitoring}

Total hydrocarbon content (THC) analysis: Total Hydrocarbon Content (THC) analyses were carried out on all the six setups using spectrophotometric method for Day 1, 5, 10, 15 and 20.

\section{Results and Discussion}

\section{Physiochemical parameters of drilling fluid contaminated} water

The $\mathrm{pH}$ of the marine water contaminated with oil base drilling 
Citation: Nrior RR, Ogbonna DN, Alabo AE (2017) Biodegradation of Drilling Fluid used in Upstream Sector of the Nigeria Petroleum Industry in Marine Water Environment. Int J Waste Resour 7: 302. doi: 10.4172/2252-5211.1000302

fluid, water base drilling fluid and control were measured respectively. The $\mathrm{pH}$ of the samples were taken every 5 days up to day 20 . The total dissolved solids of the different samples were measured using a TDS meter. The TDS meter was calibrated and then used to measure the TDS of the samples which were put in a sterile $50 \mathrm{ml}$ measuring beaker and this was done after every 5 days up to 20 (Figures 1 and 2). The Total Dissolved Solids ( $\mathrm{mg} / \mathrm{l})$ in the sample which appear in a deceasing order implies that the array of chemical contaminant is decreasing $[10,16]$.

The result of total heterotrophic bacteria and that of oil base and water base utilizing bacteria varies. Total heterotrophic bacteria count showed that the Water base contaminated marine sample have the highest count of $\log 10 \mathrm{cfu} / \mathrm{ml}(6.98,5.97,6.83,5.48,5.32)$ followed by oil base $(6.82,6.15,6.04,5.34,5.23)$ and then control $(5.15,5.85,5.84$, $5.30,5.20$ ) (Figure 3 ). This shows a decrease in the number of colonies as days passes. The population levels of hydrocarbon utilizers and their proportions within the microbial community appear to be a sensitive index of environmental exposure to hydrocarbon [17].

Fungi population showed similar trend but with a lower value comparative to Total Heterotrophic bacteria; Fungal counts ( $\log 10$ $\mathrm{cfu} / \mathrm{ml}$ ); Water based drilling fluid contaminated marine water have the highest value of $\log 10 \mathrm{cfu} / \mathrm{ml}$ with Water based drilling fluid (5.90, 4.78, 4.48, 4,48, 4.30); Oil based drilling fluid contaminated marine water $(4.95,4.70,4.30,4.00,3.00)$; Control, habitat marine water only $(4.48,4.0,3.85,3.70,3.48)$ (Figure 4). Drilling fluid utilizing bacterial population relatively reflect a decreasing trend from day zero to day 20 ; with Water based drilling fluid contaminated marine water having the highest value $(\log 10 \mathrm{cfu} / \mathrm{ml})$; water based drilling fluid $(5.48,5.70,5.48$, $4.48,4.30)$; oil base drilling fluid contaminated marine water $(4.78$, $4.70,4.48,4.48,4.30)$; control, habitat marine water only $(4.70,4.60$, $4.48,4.30,4.0$ ) (Figure 5)

Figure 5 shows that the microrganisms decreases as the day goes by, but at a point the number of colonies became stable. The relative occurrence of specific genera of bacteria could be used as an index of the pollution status or biodegradation potential of an environment [18]; this fact clearly emphasizes the thought that the significance of occurrence may be due to the fact that Pseudomonas and Bacillus are more adapted to survival and biodegradation capabilities in marine water environment. Drilling fluid utilizing bacteria isolates were Pseudomonas, Bacillus, Micrococcus and Enterobacter, with Pseudomonas having the highest frequency of $35.7 \%$, followed by Bacillus with the frequency of $30.7 \%$, Micrococcus had $15.4 \%$ and Enterobacter $15.4 \%$ (Figure 6) while fungi genera were; Aspergillus, Penicillium, Rhizopus and Mucor. These group of microorganisms are no doubt the normal flora of any situation that has to do with dulling fluid or mud in most familiar studies $[13,19]$.

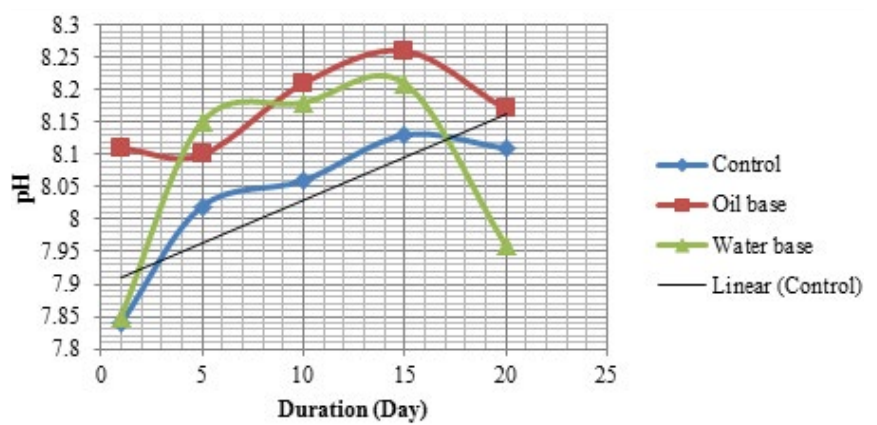

Figure 1: Hydrogen ion concentration $(\mathrm{pH})$ during biodegradation of drilling fluid in marine water.

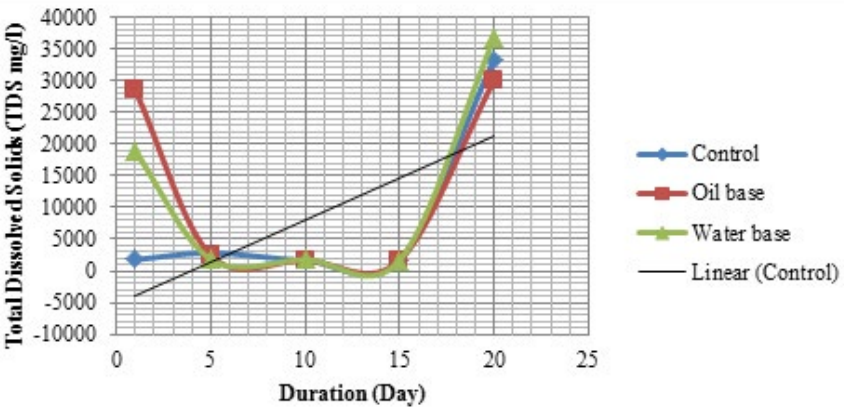

Figure 2: Total dissolved solids (TDS $\mathrm{mg} / \mathrm{l}$ ) during biodegradation of drilling fluid in marine water.

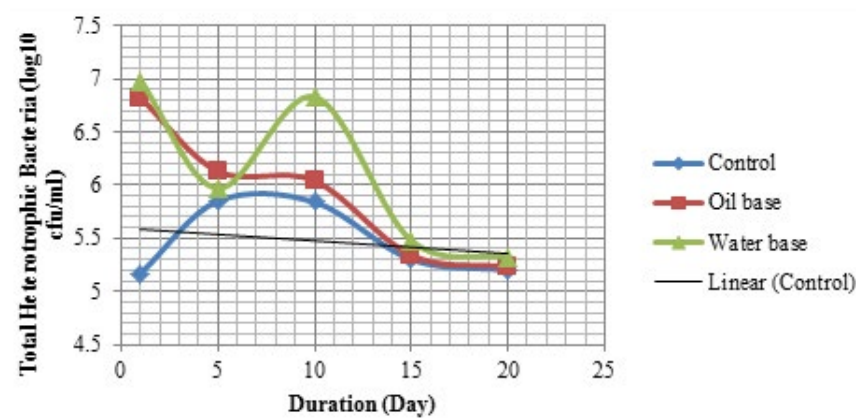

Figure 3: Total heterotrophic bacteria $(\log 10 \mathrm{cfu} / \mathrm{ml})$ during biodegradation of drilling fluid in marine water.

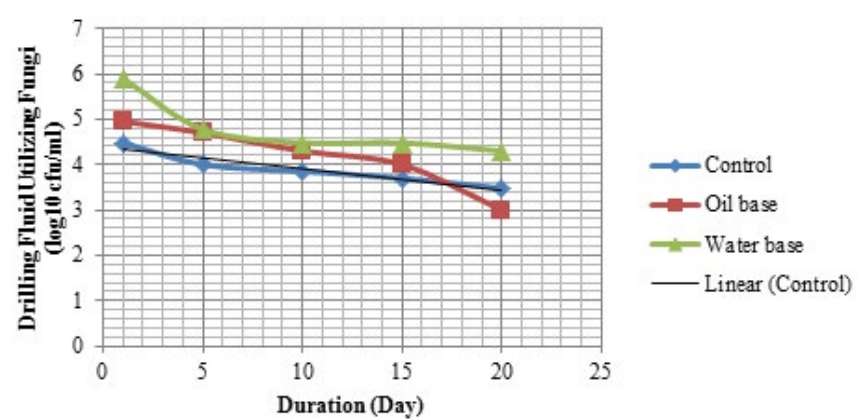

Figure 4: Drilling fluid utilizing fungi $(\log 10 \mathrm{cfu} / \mathrm{ml})$ during biodegradation of drilling fluid in marine water.

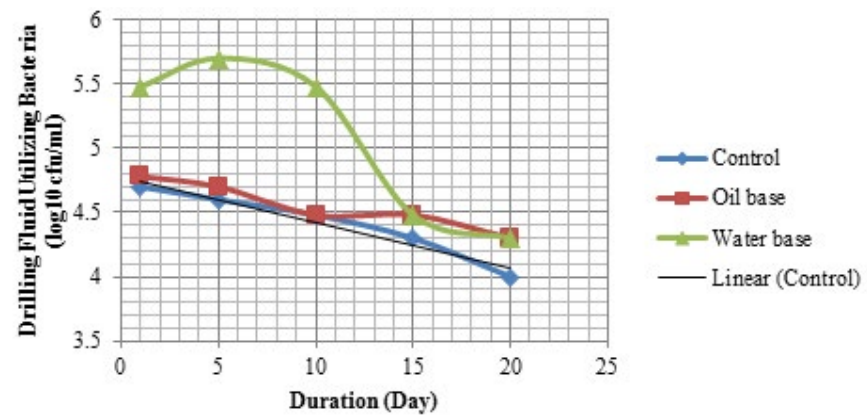

Figure 5: Drilling fluid utilizing bacteria $(\log 10 \mathrm{cfu} / \mathrm{ml})$ during biodegradation of drilling fluid in marine water. 
Figure 7 shows the occurrence of the microorganism as a result of their ability to either tolerate and biodegrade the drilling fluid and its products.

In the course of this study it has been revealed that the two drilling fluids is somehow toxic to some microorganisms and therefore reduced the number of microorganisms in the sample as the days goes by (Figures 3-5). The most frequently isolated microorganisms that degrade drilling fluids are Pseudomonas followed by Bacillus, Micrococcus and Enterobacter as seen in Figure 6.

These bacteria are able to colonize the drilling fluid/hydrocarbon contaminated marine water and degrade them (Figure 7) because of their genetic composition and their occurrence during the days of experiment [10].

From Figure 7, the initial calculable Total hydrocarbon content (THC $-\mathrm{mg} / \mathrm{l}$ ) varies between the two types of drilling fluid (oil base drilling fluid $90 \mathrm{mg} / \mathrm{l}$; water base drilling fluid $96 \mathrm{mg} / \mathrm{l}$ ) while at day 20, the residual Total Hydrocarbon Content (THC - mg/l) were (oil base drilling fluid $46 \mathrm{mg} / \mathrm{l}$; water base drilling fluid $50 \mathrm{mg} / \mathrm{l})$. The rate of biodegradation of water base drilling fluid (59.5\%) while oil base drilling fluid (54.2\%) (Figure 8).

The data analysis on percentage (\%) rate of biodegradability shows

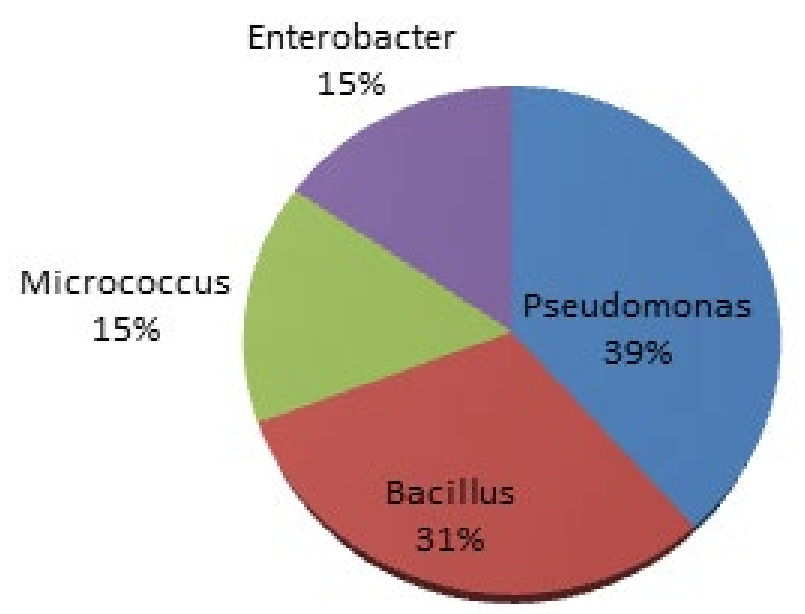

Figure 6: Percentage frequency of bacteria isolated from drilling fluid contaminated marine water.

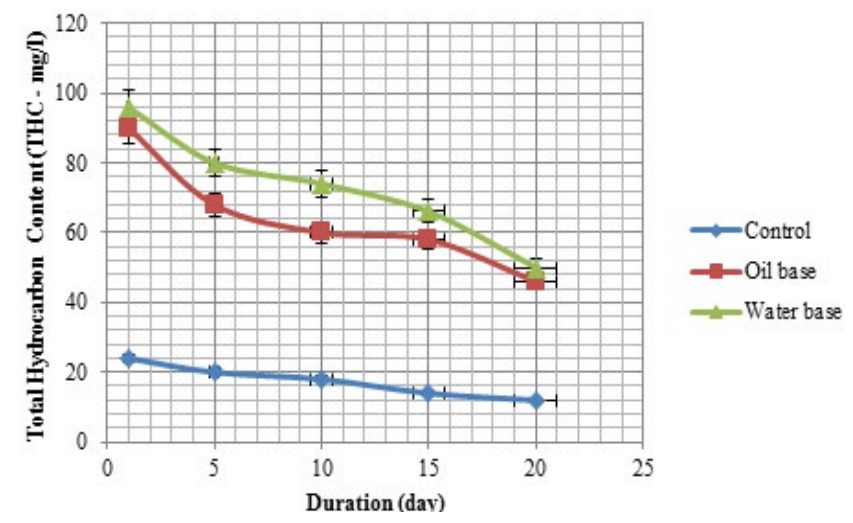

Figure 7: Total hydrocarbon content $(\mathrm{THC}-\mathrm{mg} / \mathrm{l})$ of drilling fluids during its biodegradation in marine water.

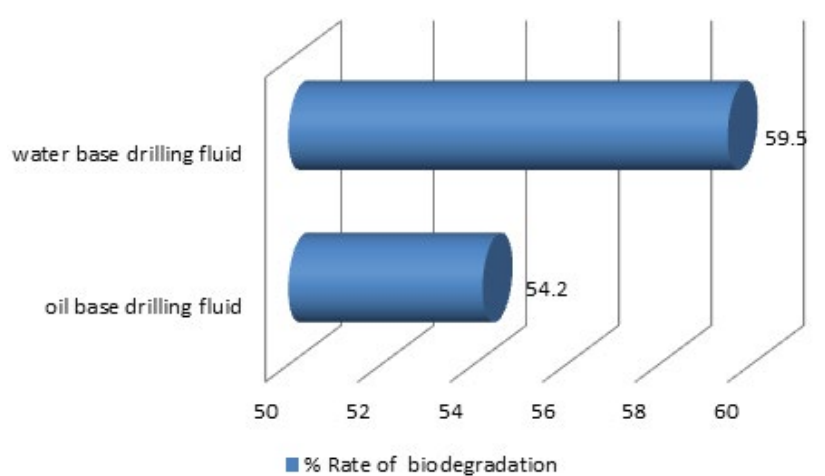

Figure 8: Percentage (\%) rate of biodegradation of drilling fluid in marine water.

water base drilling fluid to be more degradable than oil base drilling fluid Figure 8. These data in the reports serve as a good start in the better understanding the fate and effect of drilling fluid/mud in the Nigeria marine environment as a result of accidental spills or routine discharges of drill cuttings material.

\section{Conclusion}

Conclusively, the study showed that Water based drilling fluid is more biodegradable in marine water environment than Oil based drilling fluid. Therefore it is recommended that since most oil well drilling activities in Nigeria are carried out in marine environment, water based drilling fluid should be the best option due to its high degradability rate.

In the course of this study it has been revealed that the two drilling fluids is somehow toxic to some microorganisms and therefore reduced the number of microorganisms in the sample as the days goes by. The most frequently isolated microorganisms that degrade drilling fluids are Pseudomonas followed by Bacillus, Micrococcus and Enterobacter However, it is important to note that the persistence and degradation effect in deep marine seawater/sediments may vary from the data that were obtained in the laboratory tests due to other factors that can affect the ultimate biodegradation rate of the fluids. Since environmental conditions in the sea vary from one location to another, it is not possible to develop a standardized procedure for biodegradability that covers all environmental conditions.

\section{References}

1. Alexander M (1994) Biodegradation and bioremediation.

2. API (1992) American Petroleum Institute: Drilling fluid and laboratory testing of drilling fluid.

3. Gesamp (1997) Marine biodiversity pattern, threats and conservation needs.

4. Bol GM, Wong SW, Davidson CJ, Woodland DC (1992) Borehole stability in shales.

5. Young SY, Maas T (2001) Novel polymer chemistry increases shale stability Drilling Technology, American Association of Drilling Engineers, AADE National Drilling Technical Conference, AADE 01-NC-HO-41, Houston (TX).

6. Schlemmer R, Friedheim JE, Growcock FB, Headley JA, Polnaszek SC, et al. (2002) Membrane efficiency in shale - an empirical evaluation of drilling fluid chemistries and implications of fluid design. IADC/SPE Paper 74557 Presented at IADC/SPE Drilling Conference in Dallas, Texas.

7. Zhanpeng J, Hongwei Y, Lixin S, Shaoqi S (2002) Integrated assessment for aerobic biodegradability of organic substances. Chemosphere 48: 133-138

8. Cole MG (1994) Assessment and remediation of petroleum contaminated sites CRC Press, Boca Raton, FL. p. 63. 
Citation: Nrior RR, Ogbonna DN, Alabo AE (2017) Biodegradation of Drilling Fluid used in Upstream Sector of the Nigeria Petroleum Industry in Marine Water Environment. Int J Waste Resour 7: 302. doi: 10.4172/2252-5211.1000302

Page 5 of 5

9. Okpokwasili GC (2003) Biodegradation potentials of microorganisms isolated from car engine lubricating oil. Tribol Int 21: 215-220.

10. Nrior RR, Wosa C (2016). Biodegradation of oil spill dispersant in brackish water ecosystem of the Niger Delta, Nigeria. Journal of International Society of Comparative Education, Science and Technology (ICEST) 3: 187-201.

11. No Authors Listed (2012) Standard methods for the examination of water and wastewater (22nd edn.), American Public Health Association; American Water Works Association; Water Environmental Federation, Washington DC, USA.

12. Odokuma LO, Okpokwasili GC (1992) Role of composition in the degradability of oil spill dispersants. Waste Management 12: 39-43.

13. Nrior RR, Odokuma LO (2015). Ultimate biodegradability potential of trichloroethylene (TCE) used as degreaser in marine, brackish and fresh water. Journal of Environmental Sciences, Toxicology and Food Technology 9: 80-89.

14. Cheesbrough M (2006) District laboratory practice in tropical countries.
15. Nrior RR, Echezolom C (2016) Assessment of percentage bioremediation of petroleum hydrocarbon contaminated soil with biostimulating agents. Journa of International Society of Comparative Education, Science and Technology 3: $203-215$.

16. Bruvold WH, Pangborn RM (1996) Rates acceptability of mineral taste in water J Appl Psychol 50: 22

17. Atlas RM (1993) Microbial degrading petroleum hydrocarbons: An environmenta perspective. Microbiology Reviews 45: 180-209.

18. Odu CTI (1981) Degradation and weathering of crude oil under tropical conditions in the petroleum industry. Nigeria Environment Proceeding of the 1981 internal seminar.

19. Khodja M (2008) Drilling fluid: Performance study and environmental consideration. Thesis National Polytechnic Institute, Toulouse, France. 